\title{
INTERFERENCE WITH CELLULAR INCORPORATION OF SUBSTRATES INTO STAPHYLOCOCCUS AUREUS BY HORMONES
}

\author{
T. Fitzgerald AND W. W. Yotis \\ Department of Microbiology, Loyola University (Chicago) \\ Stritch School of Medicine, Maywood, Illinois 60153, USA
}

STER OIDS effectively diminish the growth of staphylococci in nutrient broth; they interfere with the development of staphylococcal furunculosis in rabbits, and inhibit the proliferation of staphylococci experimentally introduced into the spleens and kidneys of mice (Yotis and Stanke, 1966; Yotis, 1967; Yotis and Fitzgerald, 1968; Yotis and Waner, 1968; Yotis and Baman, 1969 $a$ and $b$; Yotis and Cummings, 1969). In attempting to explain this bacteriostasis, consideration has been given to hormonal intervention in the incorporation of nutrients. In the preceding paper in this issue (Fitzgerald and Yotis, 1971) we related the hormonal retardation of the growth of Staphylococcus aureus in vitro with interference in the uptake of alanine and glutamic acid, and we demonstrated optimal parameters for studying these inhibitory effects. The present study was undertaken to extend the previous findings. The data indicate that steroids significantly influence the incorporation of a number of substrates involved in the synthesis of various macromolecules by Staph. aureus.

\section{MATERIALS AND METHODS}

Strains. The details of the source, maintenance and biological assays of the staphylococcal strains employed have been described (Fitzgerald and Yotis). Escherichia coli and Shigella flexneri were obtained from stock culture collections maintained at the Stritch School of Medicine and were originally obtained from the American Type Culture Collection.

Hormone solutions. Hormones were dissolved in 95 per cent. ethanol and diluted as previously described (Fitzgerald and Yotis).

Chemicals. Crystalline progesterone, epiandrosterone, stanolone and $17 \alpha$-hydroxyprogesterone were obtained from Sigma Chemical Co., St Louis, Mo. The following labelled compounds were obtained from Tracerlab, Waltham, Mass.: adenine-8-14C, L-alanine-14C (uniformly labelled, u.1.), L-glutamic acid-14C (u.1.), L-phenylalanine-14C (u.1.), sodium acetate-1-14C, glycerol-14C (u.1.), D-glucose- ${ }^{14} \mathrm{C}$ (u.1.), uracil-2-14C, L-leucine-14C (u.1.) and L-lysine-14C (u.1.).

Synthetic medium. The synthetic medium of Hancock and Park (1958) was utilised for studies of the incorporation of the various substrates. The medium was slightly modified whenever the incorporation of one of its constituents was studied by deleting that $12 \mathrm{C}$ constituent.

Procedures for the study of uptake, incorporation, and methods of fractionation of bacteria. A smooth bacterial suspension was prepared (Yotis and Fitzgerald, 1968) in synthetic medium and pre-incubated for $45 \mathrm{~min}$. on a shaker at $37^{\circ} \mathrm{C}$. A specified volume of cells was added

Received 12 June 1970; accepted 2 July 1970.

J. MED. MICROBIOL.-VOL. 4 (1971) 
to $0.1 \mathrm{mCi}$ of the labelled substrate in the presence and absence of the hormone(s). After incubation for $15 \mathrm{~min}$. at $24^{\circ} \mathrm{C}$, the suspension was immediately centrifuged and washed twice with cold saline at $4^{\circ} \mathrm{C}$. The bacteria were fractionated according to the procedure of Park and Hancock (1960): the cold trichloroacetic acid (TCA) extract contains the pool amino acids and other acid-soluble components of low molecular weight. Extraction of the TCA-insoluble residue with $\mathbf{7 5}$ per cent. ethanol yields cellular lipids and small amounts of protein. Extraction with hot TCA removes the nucleic acids and virtually all the teichoic acids from the cell wall. Treatment of the hot TCA-insoluble fraction with trypsin converts about 95 per cent. of the cell protein to soluble peptides. The residue consists predominantly of the mucopeptide of the wall structure. $0 \cdot 1-\mathrm{ml}$ volumes of each soluble fraction were added to the scintillation medium (Davidson and Feigelson, 1957). The insoluble residue was separated by Millipore filtration (Millipore Corporation, New Bedford, Mass.; 0.45 $\mu \mathrm{m}$ pore size). The filters were washed with 5 vol. cold buffer, air-dried, and placed directly into the scintillation fluid (Mans and Novelli, 1961). Radioactivity was assayed in a Packard Tri-carb liquid scintillation spectrometer model 3320.

Studies of short-term incorporation. A modification of the above procedure was required for the short-term alanine studies involving 10- and 60-s incubations. Cells were added to $0.2 \mathrm{mCi}$ of the labelled amino acid in the presence and absence of progesterone in 1 per cent. ethanol; the progesterone-free control suspensions received an equivalent amount of 1 per cent. ethanol. At the specified time, 2 vol. ice water were added to the test mixture. This was placed in a waterbath at $4^{\circ} \mathrm{C}$ for $10 \mathrm{~min}$., centrifuged and washed twice at $4^{\circ} \mathrm{C}$ and fractionated as described.

Statistical analysis. All data were subjected to statistical analysis (Batson, 1956). A " $t$ " test result greater than 2.0 indicates statistical significance.

\section{RESULTS}

\section{Effect of progesterone on amino acid incorporation in staphylococci}

A smooth suspension of staphylococci in synthetic medium was added to $0.1 \mathrm{mCi}$ of ${ }^{14} \mathrm{C}$-labelled amino acid (glutamic acid, lysine or alanine) in the presence and absence of progesterone at a concentration of $40 \mu \mathrm{g}$ per $\mathrm{ml}$. Incubation was terminated $15 \mathrm{~min}$. after addition of the label. The data summarised in table I show that entrance of glutamic acid and alanine into the cellular pools, as indicated by our studies with the cold TCA fractions, was inhibited by 13 per cent. and 16 per cent. respectively in comparison with controls, whereas the entrance of lysine was stimulated by 46 per cent. Our results with the ethanol-soluble fractions, containing ethanol-soluble protein and lipids indicate that the hormone reduced the entry of the three amino acids by 16 to 21 per cent. The relatively large quantities of radioactivity in the lysine fraction can be attributed to the formation of lysyl-phosphatidylglycerol phosphate (Houtsmuller and Van Deenen, 1964). Progesterone impeded the entrance of lysine and alanine into the hot TCA fraction by 11 per cent. and 45 per cent. respectively. Armstrong et al. (1958) showed that the teichoic acid from staphylococci contains O-alanyl groups attached to ribitol phosphate polymers. This accounts for the large amount of ${ }^{14} \mathrm{C}$-activity after exposure to the labelled alanine. The hormone stimulated the incorporation of glutamic acid into the protein and mucopeptide fractions but, in direct contrast, progesterone inhibited the incorporation of lysine and alanine into the protein and mucopeptide fractions. 
Comparative studies with staphylococci and Gram-negative bacteria

Suspensions of Staphylococcus aureus, Escherichia coli and Shigella flexneri were exposed in parallel to $0.1 \mathrm{mCi}$ of ${ }^{14} \mathrm{C}$-alanine for $15 \mathrm{~min}$. in synthetic medium, in the presence and absence of progesterone at a concentration of $40 \mu \mathrm{g}$ per $\mathrm{ml}$. Subsequent fractionation revealed (table II) that the amount of radioactivity in each fraction of $E$. coli and $S h$. flexneri was not significantly

\section{TABLE I}

The inhibitory effect of progesterone on amino acid incorporation in staphylococci

\begin{tabular}{|c|c|c|c|c|c|c|c|c|c|}
\hline \multirow{2}{*}{$\begin{array}{c}\text { Extraction } \\
\text { procedure } \\
\text { providing } \\
\text { cell } \\
\text { fraction }\end{array}$} & \multicolumn{3}{|c|}{$\begin{array}{l}\text { Glutamic acid } \\
\text { incorporation* }\end{array}$} & \multicolumn{3}{|c|}{ Lysine incorporation* } & \multicolumn{3}{|c|}{ Alanine incorporation* } \\
\hline & $\frac{\frac{0}{8}}{\frac{8}{0}}$ & 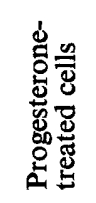 & 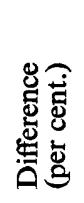 & $\begin{array}{l}\frac{n}{0} \\
0 \\
0 \\
0 \\
0 \\
0\end{array}$ & 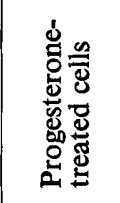 & 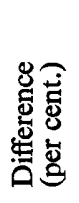 & $\frac{\stackrel{0}{\overline{8}}}{\frac{0}{0}}$ & 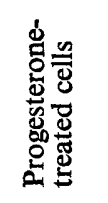 & 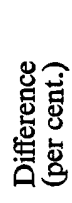 \\
\hline Cold TCA $\dagger$ & 9200 & 8000 & $13 \cdot 0$ & 124,240 & 231,640 & $46 \cdot 4$ & 32,626 & 27,306 & $16 \cdot 3$ \\
\hline 75 per cent. ethanol & 1413 & 1186 & $16 \cdot 1$ & 23,266 & 18,320 & $21 \cdot 2$ & 4706 & 3933 & $16 \cdot 4$ \\
\hline Hot TCA $\uparrow$ & 4880 & 4773 & $2 \cdot 2$ & 6213 & 5514 & $11 \cdot 2$ & 37,466 & 20,453 & $45 \cdot 4$ \\
\hline Trypsin solution & 43,226 & 52,293 & $17 \cdot 3$ & 36,373 & 32,560 & $10 \cdot 5$ & 39,353 & 33,766 & $14 \cdot 2$ \\
\hline Residue & 2658 & 3075 & $13 \cdot 6$ & 36,470 & 31,692 & $13 \cdot 1$ & 19,581 & 15,622 & $29 \cdot 1$ \\
\hline
\end{tabular}

* Expressed as counts per minute per $30 \mathrm{ml}$ cells. The values for percentage differences that are statistically significant are shown in bold type.

$\uparrow$ TCA $=$ Trichloroacetic acid.

influenced by the hormone. In contrast, the five fractions of Staph. aureus showed significant reduction (by 14-45 per cent.) in amounts of radioactivity in the hormone-treated cells.

\section{Effect of concentration of progesterone}

Staphylococci were exposed to progesterone at concentrations of $0,1,15$, 30 and $40 \mu \mathrm{g}$ per $\mathrm{ml}$ and $0 \cdot 1 \mathrm{mCi}$ of ${ }^{14} \mathrm{C}$-alanine for $15 \mathrm{~min}$. No significant difference was apparent in the quantity of radioactivity within fractions of control cells and cells exposed to the hormone at $1 \mu \mathrm{g}$ per ml. At concentrations above $15 \mu \mathrm{g}$ per $\mathrm{ml}$, however, there was a progressive increase in inhibition of entry of the ${ }^{14} \mathrm{C}$-label into all five fractions. These results are summarised in table III. 
TABLE II

The effects of progesterone on alanine incorporation into various bacteria

\begin{tabular}{|c|c|c|c|c|c|c|c|c|c|}
\hline \multirow{2}{*}{$\begin{array}{l}\text { Extraction } \\
\text { procedure } \\
\text { providing } \\
\text { cell } \\
\text { fraction }\end{array}$} & \multicolumn{3}{|c|}{$\begin{array}{l}\text { Incorporation in } \\
\text { Staph. aureus* }\end{array}$} & \multicolumn{3}{|c|}{$\begin{array}{l}\text { Incorporation in } \\
\text { E. coli* }\end{array}$} & \multicolumn{3}{|c|}{$\begin{array}{l}\text { Incorporation in } \\
\text { Sh. flexneri }\end{array}$} \\
\hline & $\begin{array}{l}\frac{n}{8} \\
\frac{0}{0} \\
\stackrel{0}{0} \\
8\end{array}$ & 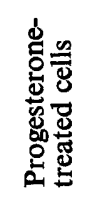 & 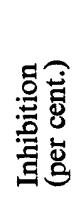 & $\begin{array}{l}\frac{\infty}{\bar{\Xi}} \\
\overline{0} \\
\frac{0}{0} \\
\delta\end{array}$ & 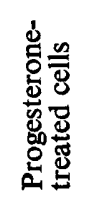 & 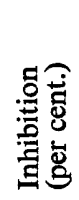 & $\begin{array}{l}\frac{a}{\overline{8}} \\
\frac{0}{0} \\
\text { ठ }\end{array}$ & 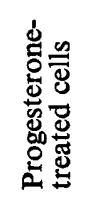 & 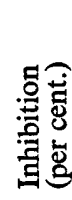 \\
\hline Cold TCA $\dagger$ & 32,626 & 27,306 & $16 \cdot 3$ & 2000 & 2380 & $\cdots$ & 3920 & 4220 & $\cdots$ \\
\hline 75 per cent. ethanol & 4706 & 3933 & $16 \cdot 4$ & 2620 & 2840 & $\ldots$ & 2040 & 2300 & ... \\
\hline Hot TCA $\dagger$ & 37,466 & 20,453 & $45 \cdot 4$ & 2640 & 2820 & $\ldots$ & 2860 & 3020 & $\ldots$ \\
\hline Trypsin solution & 39,353 & 33,766 & $14 \cdot 2$ & 21,140 & 22,040 & $\ldots$ & 20,100 & 22,180 & $\cdots$ \\
\hline Residue & 19,551 & 15,622 & $20 \cdot 1$ & 1678 & 1740 & $\ldots$ & 1514 & 1700 & $\ldots$ \\
\hline
\end{tabular}

* Expressed as counts per minute per $30 \mathrm{ml}$ cells. The values for percentage inhibition that are statistically significant are shown in bold type.

$\dagger$ TCA $=$ Trichloroacetic acid.

TABLE III

The effect of varying concentrations of progesterone on the incorporation of alanine in staphylococci

\begin{tabular}{l|r|r|r|r|r|r|r|r|r}
\hline & \multicolumn{7}{|c}{ Alanine incorporation* at the given progesterone concentration (PC) and } \\
the degree of inhibition observed \\
$\begin{array}{l}\text { Extraction } \\
\text { procedure } \\
\text { providing } \\
\text { cell } \\
\text { fraction }\end{array}$
\end{tabular}

* Expressed as counts per minute per $30 \mathrm{ml}$ cells. The values for percentage inhibition that are statistically significant are shown in bold type.

$\uparrow$ TCA $=$ Trichloroacetic acid. 


\section{Effects of other hormones}

Previous comparative studies (Yotis and Stanke, 1966; Yotis and Fitzgerald, 1968) of the action of gonadal hormones on the multiplication of staphylococci showed that epiandrosterone at a concentration of $20 \mu \mathrm{g}$ per $\mathrm{ml}$ or more markedly inhibited growth, stanolone slightly inhibited, and 17 $\alpha$-hydroxyprogesterone did not inhibit the growth of Staph. aureus. With these facts in mind, alanine incorporation was assayed in the presence of each hormone at $40 \mu \mathrm{g}$ per $\mathrm{ml}$ and a similar study was done with epiandrosterone at $10 \mu \mathrm{g}$ per $\mathrm{ml}$ (table IV). Bacteria were exposed to $0.1 \mathrm{mCi}$ of ${ }^{14} \mathrm{C}$-alanine for $15 \mathrm{~min}$. and

TABLE IV

Effects of various hormones on the incorporation of alanine in staphylococci

\begin{tabular}{l|r|r|r|r|r|r|r|r|r}
\hline & \multicolumn{7}{|c}{ Alanine incorporation* in the presence of the given hormone and } \\
the degree of inhibition observed \\
$\begin{array}{c}\text { Extraction } \\
\text { procedure } \\
\text { providing } \\
\text { cell } \\
\text { fraction }\end{array}$
\end{tabular}

* Expressed as counts per minute per $30 \mathrm{ml}$ cells. The values for percentage inhibition that are statistically significant are shown in bold type.

$\dagger \mathrm{TCA}=$ Trichloroacetic acid.

fractionated. Note that $17 \alpha$-hydroxyprogesterone did not significantly reduce entrance of the label into any of the fractions; epiandrosterone at a concentration of $10 \mu \mathrm{g}$ per $\mathrm{ml}$ inhibited entrance into the protein fraction only; and stanolone affected entrance of the labelled alanine into both the hot TCA and protein fractions, producing 12 per cent. and 19 per cent. inhibition. Epiandrosterone at $40 \mu \mathrm{g}$ per $\mathrm{ml}$ produced maximum inhibition, impeding entrance of the label into all five fractions by $10-38$ per cent.

\section{Short-term exposure studies}

It is known that substrates such as amino acids, taken into cells and incorporated into cellular components, must pass through a cellular pool before 
entering the various metabolic pathways (Zalokar, 1961; Britten and McClure, 1962; Britten, 1963). In this manner, the pool size may directly influence the synthesis of macromolecules. Therefore, it was important to determine the point at which initial hormonal effects occurred. To this end, short-term uptake experiments were performed with alanine. Staphylococci were exposed for 10, 60 and $900 \mathrm{~s}$ to $0.2 \mathrm{mCi}{ }^{14} \mathrm{C}$-alanine in the presence and absence of progesterone

TABLE V

A study of the kinetics of the effect of progesterone on staphylococcal incorporation of alanine

\begin{tabular}{|c|c|c|c|c|c|c|c|c|c|}
\hline \multirow{3}{*}{$\begin{array}{l}\text { Extraction } \\
\text { procedure } \\
\text { providing } \\
\text { cell } \\
\text { fraction }\end{array}$} & \multicolumn{9}{|c|}{$\begin{array}{l}\text { Alanine incorporation* at the stated time for the given preparation and } \\
\text { the degree of inhibition observed }\end{array}$} \\
\hline & \multicolumn{3}{|c|}{10 seconds } & \multicolumn{3}{|c|}{60 seconds } & \multicolumn{3}{|c|}{900 seconds } \\
\hline & 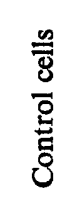 & 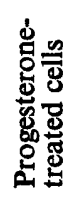 & 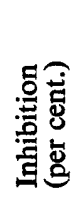 & 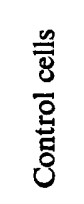 & 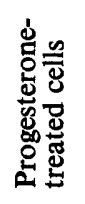 & 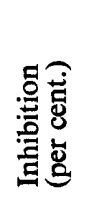 & 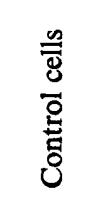 & 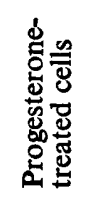 & 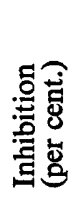 \\
\hline Cold TCA $\dagger$ & 3550 & 3000 & $15 \cdot 5$ & 4070 & 3500 & $14 \cdot 0$ & 32,626 & 27,306 & $16 \cdot 3$ \\
\hline Hot TCA $\dagger$ & 4550 & 4300 & $5 \cdot 5$ & 5800 & 4550 & $21 \cdot 5$ & 37,466 & 20,453 & $45 \cdot 4$ \\
\hline Trypsin solution & 7410 & 7690 & $\ldots$ & 8890 & 8980 & $\ldots$ & 39,353 & 33,766 & $14 \cdot 2$ \\
\hline Residue & 2420 & 2278 & $5 \cdot 9$ & 4000 & 3780 & $5 \cdot 5$ & 19,551 & 15,622 & $20 \cdot 1$ \\
\hline
\end{tabular}

* Expressed as counts per minute per $30 \mathrm{ml}$ cells. The values for percentage inhibition that are statistically significant are shown in bold type.

$\dagger$ TCA $=$ Trichloroacetic acid.

at $40 \mu \mathrm{g}$ per $\mathrm{ml}$. The initial inhibition occurred in the cold TCA fraction at $10 \mathrm{~s}$, and there was increasing inhibition of ${ }^{14} \mathrm{C}$ entrance into the hot TCA fraction: 5 per cent. at $10 \mathrm{~s}, 21$ per cent. at $60 \mathrm{~s}$, and 45 per cent. at $900 \mathrm{~s}$ (table V). With the protein and residue fractions, hormonal intervention was not apparent until staphylococci had been exposed for more than $60 \mathrm{~s}$. The results strongly indicate that the initial hormonal influence was exerted on the transport of alanine into the cellular pool.

\section{Effects of progesterone on the pool size of other substrates}

The above data prompted a comparative study of hormonal effects on other substrates. Uptake of the ${ }^{14} \mathrm{C}$-compound was terminated $15 \mathrm{~min}$. after addition of $0.1 \mathrm{mCi}$ of the radioactively labelled substrate in the presence and absence of progesterone at $40 \mu \mathrm{g}$ per $\mathrm{ml}$ in 1 per cent. ethanol; the progesterone-free mixtures received 1 per cent. ethanol (table VI). The test substrates and the 
results are listed in table VI. The hormone altered the cellular pool size of eight of the ten substrates tested. Significant inhibition ranged from 17 per cent. for adenine to 11 per cent. for glycerol. Lysine uptake was stimulated 46 per cent. whereas uptake of glucose and uracil was not affected.

TABLE VI

Effects of progesterone on cellular pool sizes of various substrates

\begin{tabular}{l|c|c|c}
\hline & \multicolumn{3}{|c}{$\begin{array}{c}\text { Cellular pool size* in the given preparation } \\
\text { and the difference observed }\end{array}$} \\
\cline { 2 - 3 } \multicolumn{1}{c|}{ Substrate } & $\begin{array}{c}\text { Control } \\
\text { cells }\end{array}$ & $\begin{array}{c}\text { Progesterone- } \\
\text { treated cells }\end{array}$ & $\begin{array}{c}\text { Difference } \\
\text { (per cent.) }\end{array}$ \\
\hline & 45,768 & 37,948 & $17 \cdot 1$ \\
Adenine & 32,626 & 27,306 & $\mathbf{1 6 \cdot 3}$ \\
Alanine & 9200 & 8000 & $\mathbf{1 3 \cdot 0}$ \\
Glutamic acid & 13,800 & 12,120 & $\mathbf{1 2 \cdot 2}$ \\
Phenylalanine & 3480 & 3080 & $\mathbf{1 1 \cdot 5}$ \\
Acetate & 42,270 & 37,640 & $\mathbf{1 0} \cdot 9$ \\
Glycerol & 7400 & 6630 & $\mathbf{1 0 \cdot 4}$ \\
Leucine & 48,060 & 46,240 & $3 \cdot 8$ \\
Glucose & 170,730 & 168,190 & $1 \cdot 5$ \\
Uracil & 124,240 & 231,640 & $\mathbf{4 6} \cdot 4$ \\
Lysine & &
\end{tabular}

* Expressed as counts per minute obtained with the cold TCA extract of a 30-ml volume of cell suspension. The values for percentage difference that are statistically significant are shown in bold type.

\section{Discussion}

The data presented in this paper indicate that hormones, in the pharmacological concentrations required to retard the in-vitro growth of Staph. aureus, alter the organism's ability to incorporate a number of substrates. Our observation of the effects of steroids on the incorporation of glutamic acid, lysine and alanine into cellular macromolecules provokes some interesting speculation. That progesterone influences the synthesis of protein and mucopeptide is suggested by the observed inhibition of uptake of lysine and alanine and the stimulation of entry of glutamic acid into the trypsin-soluble and residue fractions. More rigorous experimentation is required to substantiate this suggestion.

A second observation concerns the permeability systems of these three amino acids. Gale (1953) examined the exogenous energy requirements for staphylococcal uptake systems and found that alanine was taken up by an energy-independent system and glutamic acid by an energy-dependent system. Thus, if hormonal intervention occurred at some specific energy-requiring step, maximum effects should occur in glutamic acid uptake and minimum effects in alanine uptake. Progesterone reduced entrance of both glutamic acid (by 13 per cent.) and alanine (by 16 per cent.) into the cold TCA fractions. It appears, then, that hormonal intervention in amino acid uptake does not involve specific exogenous energy requirements. 
The data presented in tables II, III and IV are well correlated with results of previous in-vitro studies on steroidal inhibition of bacterial growth in nutrient broth (Yotis and Stanke, 1966; Yotis and Fitzgerald, 1968). The steroids did not retard the growth of Gram-negative organisms and, likewise, did not reduce the incorporation of alanine into E. coli and Sh.flexneri. A minimum progesterone concentration of $15 \mu \mathrm{g}$ per ml was required to inhibit growth of Staph. aureus; incorporation of alanine was similarly affected and there was increasing inhibition with increasing concentrations of the hormone. Our previous studies showed that at $40 \mu \mathrm{g}$ per $\mathrm{ml}$, epiandrosterone greatly reduced staphylococcal growth in broth; stanolone produced a slight reduction, and 17 $\alpha$-hydroxyprogesterone did not influence growth. Identical results were obtained for alanine incorporation in our present studies; epiandrosterone was the most potent inhibitor, stanolone inhibited to a lesser degree and 17 $\alpha$-hydroxyprogesterone exerted no effect whatsoever. Moreover, we previously noted that epiandrosterone retarded staphylococcal growth only at a concentration of $20 \mu \mathrm{g}$ per $\mathrm{ml}$ or greater. When we tested this hormone in the present studies at $10 \mu \mathrm{g}$ per ml, it did not significantly alter the incorporation of alanine into four of the five cellular fractions.

The short-term incorporation studies demonstrated that the initial hormonal inhibition occurs at the stage of the entrance of alanine into the cellular pool. Retardation of entry of the label into the nucleic acid, protein and residue fractions, however, required prolonged exposure. The reduction in the rate of entrance of a substrate leads to a smaller pool size of that substrate. This smaller pool, in turn, may reduce the rate of passage of the substrate into the various cellular macromolecules such as proteins, teichoic acids and mucopeptides.

Our further data show that the hormonal interference in the entrance of substrates is not limited to a few amino acids, but appears to be a general phenomenon involving a number of other substrates.

Mandelstam (1956) investigated the passage of basic amino acids into Staph. aureus and E. coli. He attributed the growth-inhibitory phenomenon to an interference in the penetration of an essential factor(s) into bacterial cells. Lester, Stone and Hechter (1958) suggested that deoxycorticosterone limits cellular growth by direct action against specific permease systems of Neurospora crassa. Buetow and Levedahl (1964) observed early effects of steroids on permeability functions at the cell surface of Penicillium canescans. The results of the present study suggest that the growth of Staph. aureus can be selectively retarded by direct hormonal alteration of the rate of entry of substrate into the various staphylococcal macromolecules.

\section{SUMMARY}

Hormonal effects on substrate incorporation into various cellular fractions such as protein, nucleic acid and mucopeptide, have been investigated to elucidate the reported steroidal retardation of staphylococcal growth. Bacteria suspended in synthetic medium were exposed to ${ }^{14} \mathrm{C}$-compounds in the presence 
and absence of hormones. Progesterone at $40 \mu \mathrm{g}$ per $\mathrm{ml}$ significantly altered the entrance of glutamic acid, lysine and alanine into all cellular fractions of Staphylococcus aureus. With progesterone and epiandrosterone, the critical concentrations required to reduce incorporation of ${ }^{14} \mathrm{C}$-alanine in staphylococci were 15 and $20 \mu \mathrm{g}$ per $\mathrm{ml}$ respectively. Short-term incubation experiments with alanine revealed that the initial inhibition occurred in the entry of the ${ }^{14} \mathrm{C}$ label into the cold TCA fraction. In further studies it was found that progesterone significantly altered the entrance of eight substrates into cellular pools as indicated by studies with the cold TCA fractions. Thus, it appears as if the hormones directly influence the passage of nutrients into bacterial cells with subsequent effects on the incorporation of the nutrients into diverse cellular macromolecules. This may be related to the previously reported antimicrobial effects of hormones on staphylococci.

This investigation was supported by Public Health Service research grant AI-06618-05 from the National Institute of Allergy and Infectious Diseases.

\section{REFERENCES}

Armstrong, J. J., Baddiley, J., Buchanan, J. G., Carss, B., and Greenberg, G. R. 1958. Isolation and structure of ribitol phosphate derivatives (teichoic acids) from bacterial cell walls. J. Chem. Soc., p. 4344.

Batson, H. C. 1956. An introduction to statistics in the medical sciences, Minneapolis, p. 16.

Britten, R. 1963. The mechanism of pool formation in Escherichia coli. Recent Prog. Microbiol., 8, 49.

Britten, R. J., AND MCClure, F. T. 1962. The amino acid pool in Escherichia coli. Bact. Rev., 26, 292.

Buetow, D. E., AND LeVEDAHL, B. H. 1964. Responses of microorganisms to sterols and steroids. A. Rev. Microbiol., $18,167$.

Davidson, J. D., AND Fergelson, P. 1957. Practical aspects of internal-sample liquid-scintillation counting. Int. J. Appl. Radiat. Isotopes, $2,1$.

Fitzgerald, T., AND Yotis, W. W. 1971. Hormonal intervention in the uptake of amino acids by staphylococci. J. Med. Microbiol., 4, 89.

GALE, E. F. 1953. Assimilation of amino acids by gram-positive bacteria and some actions of antibiotics thereon. Adv. Protein Chem., 8, 285.

Hancock, R., AND PARK, J. T. 1958. Cell wall synthesis by Staphylococcus aureus in the presence of chloramphenicol. Nature, Lond., 181, 1050.

Houtsmuller, U. M. T., AND VAN DeEnen, L. L. M. 1964. On the accumulation of amino acid derivatives of phosphatidylglycerol in bacteria. Biochim. biophys. Acta, 84, 96.

Lester, G., STONE, D., AND HeChTER, O. 1958. The effects of deoxycorticosterone and other steroids on Neurospora crassa. Archs Biochem. Biophys., 75, 196.

MANDELSTAM, J. 1956. Inhibition of bacterial growth by selective interference with the passage of basic amino acids into the cell. Biochim. biophys. Acta, 22, 324.

MANS, R. J., AND Novelli, G. 1961. Measurement of the incorporation of radioactive amino acids into protein by a filter-paper disk method. Archs Biochem. Biophys., 94, 48.

Park, J. T., AND Hancock, R. 1960. A fractionation procedure for studies of the synthesis of cell-wall mucopeptides and of other polymers in the cells of Staphylococcus aureus. J. Gen. Microbiol., 22, 249.

Yotis, W. W. 1967. In vivo and in vitro action of norethindrone on staphylococci. J. Bact., 94, 1353. 
Yotis, W. W., AND BAMAN, S. 1969a. An evaluation of diethylstilbestrol as an inhibitor of the growth of staphylococci. Yale J. Biol. Med., 41, 311.

Yotis, W. W., AND BAMAN, S. 1969b. Diethylstilbestrol: a suppressor of induced furunculosis in rabbits. Yale J. Biol. Med., 41, 323.

Yotis, W. W., AND Cummings, J. M. 1969. Alteration in the multiplication of Staphylococcus aureus by Enovid. Canad. J. Microbiol., 15, 247.

Yotis, W. W., AND Fitzgerald, T. 1968. Responses of staphylococci to androgens. Appl. Microbiol., 16, 1512.

Yotis, W. W., AND STANKe, R. 1966. Bacteriostatic action of progesterone on staphylococci and other microorganisms. J. Bact., 92, 1285.

YoTIS, W. W., AND WANER, J. 1968. Antimicrobial properties of testosterone and its intermediates. Antonie van Leeuwenhoek, 34, 275.

ZALOKAR, M. 1961. Kinetics of amino acid uptake and protein synthesis in Neurospora. Biochim. biophys. Acta, 46, 423. 